\title{
A perinatális veszteséget kísérő kommunikáció jelentősége
}

\section{Communication in perinatal loss}

\section{BORNEMISZA ÁGNES}

Bornemisza Ágnes: Pécsi Tudományegyetem, Egészségtudományi Kar, Ápolástudományi, Alapozó Egészségtudományi és Védőnői Intézet; agnes.bornemisza@etk.pte.hu

Agnes Bornemisza: University of Pécs, Department of Health Visiting and Prevention, Faculty of Health Sciences; agnes.bornemisza@etk.pte.hu

\begin{abstract}
Absztrakt
A tanulmány felhívja a figyelmet a perinatális veszteséget kísérő értő intézményi kommunikáció fontosságára. A szerző szakirodalmi áttekintés és narratív interjúk segítségével mutatja be a kommunikáció torzulásainak várható hosszú távú hatásait. A perinatális veszteség során komplikált, elhúzódó gyászfolyamatra számíthatunk, ugyanakkor a támogatásra vonatkozó irányelvek teljesülését a Covid-19 kapcsán kialakuló válsághelyzet akadályozhatja.
\end{abstract}

Kulcsszavak: perinatális veszteség, gyász, kommunikáció, intézményi irányelvek, Covid-19járvány

\begin{abstract}
The article argues for the significance of responsive institutional communication in the cases of perinatal loss. The literature review as well as the results of some narrative interviews indicate that distortions in communication may have long-term detrimental impacts on the bereaving families. Perinatal loss implies a prolonged and complicated grief process. Guidelines concerning institutional support are difficult to meet in times of the Covid-19 crisis.
\end{abstract}

Keywords: perinatal loss, mourning, communication, institutional guidelines, Covid-19 pandemic

„A gyermek halálát mindennél borzalmasabbnak tartom, még nem tudjuk, hogy kit veszítünk el. A gyerek meghal, mégis egy életen át élni fog az anyában, akire rengeteg szenvedés vár, hiszen az emlék örökké benne él, és nem gondolkodik, hogy mikor és hogyan törjön a felszinre, csak azt veszi észre, hogy megint itt van, újra, újra és újra...". (Polcz Alaine)

\section{Bevezetés}

Az orvosi gyakorlatban akkor beszélünk perinatális halálról, amikor az újszülött élve született, azonban a szülést követő 168 órán belül meghalt, illetve amikor a 24. gesztációs hét után az $500 \mathrm{~g}$ vagy nagyobb súlyú, a legalább $30 \mathrm{~cm}$ hosszúságú magzat méhen belül elhalt (SZNSZK \& OGYEI, 2010). A perinatális gyász gyakran integráltalan, elszigetelt tapasztalatként van jelen a családok életében. A szülők mellett a testvérek gyásza is testi és mentális 
egészségkárosodáshoz vezethet, ennek ellenére ez a terület csak az utóbbi évtizedben vált kutatások tárgyává (Funk, Jenkins, Astroth, Braswell, \& Kerber, 2018).

Az utóbbi években már elvárásként fogalmazódik meg, hogy az orvosok és az egészségügyi szakdolgozók többek között az információk humánus, etikus kommunikálásával segítsék a perinatális veszteség feldolgozásának folyamatát (Zsák, 2020). A szülők segítésében számos eltérő területen dolgozó szakember együttese, egy interprofesszionális team vesz részt: „Az egészségügyi intézményeknek az ellátás összetett, több szakma által képviselt lehetőségeit célszerü biztositani, melyekhez tartozik a szomatikus ellátás, a pszichológiai támasznyújtás, a spirituális segités és a gyakorlati támogatás, például a temetéssel kapcsolatos kérdések." (Sz. Makó \& Veszprémi, 2017). Ilyenkor a segítés egy több lépésből álló folyamat, és a lépések közül utólag sok nem, vagy csak alig korrigálható. Éppen ezért 1985 óta számos országban szakmai útmutatót, irányelvet állítottak össze a perinatális veszteséggel kapcsolatban. Hazánkban a perinatális veszteség pszichés aspektusait, a feldolgozás lehetőségeit és a család, a környezet, valamint az egészségügy gyászfeldolgozást támogató attitüdjeit, kommunikációs szabályait a Szülészeti és Nőgyógyászati Szakmai Kollégium és az Országos Gyermekegészségügyi Intézet által kiadott irányelv foglalta össze 2010-ben (SZNSZK \& OGYEI, 2010). Így például az egészségügyi személyzettől elvárt, hogy az intézményben töltött idő alatt a családtól, barátoktól érkező érzelmi támogatás elérését segítse elő. Lehetővé kell tenni, hogy a gyászoló anyát hozzátartozói igény szerint látogathassák, és amennyiben az anya igényli, legközelebbi hozzátartozója a nap 24 órájában lehessen mellette (SZNSZK \& OGYEI, 2010).

Látható, hogy az édesanya, a szülők mentális kísérésében a szülészeti intézményekben dolgozó egészségügyi szakdolgozók, kórházi szociális munkások szerepe kiemelten fontos az ápolási napok alatt. Mivel a kórházban töltött időszak perinatális veszteség esetén gyakran csak néhány nap, rendkívüli módon összesürüsödnek a tennivalók. A gyásszal való szembenézés során a sokk szakaszának órái után a tudatosulás hosszú és gyakran gyötrő periódusa következik. Ugyanakkor ezzel párhuzamosan zajlanak a gyermekágyas anya körüli orvosi és ápolási feladatok, valamint a fogamzásgátlásra, továbbá a következő gyermekvállalásra fókuszáló tanácsadás.

\section{Normál és patológiás gyászfolyamat}

A gyász folyamatának leírása, a normál gyász fogalma is föként az európai kultúrkörben megfigyelt viselkedésmintákon alapul. Hegedűs Katalin (2012) szerint jelenleg a modern és posztmodern halálkorszak határán mozgunk, a modernitás jellemzői még megtapasztalhatók, de a posztmodernre jellemző gondolkodás is megjelenik a halál erősebb individualizációjával, a betegjogok egyre szélesedő kérdésköreivel, a hospice szellemiség térhódításával, bizonyos hagyományok újraéledésével és új rítusok kialakulásával (Mucsi, 2015).

A normál gyász fő jellemzője, hogy spontán lezajlik, azaz az esetek többségében nem igényel külső beavatkozást, szaksegítséget. A veszteség kapcsán kialakuló érzéseket, viselkedést azonban számos tényező befolyásolja: az elhunyttal való kapcsolat jellege, a halál módja, a gyászoló életkora, neme, személyisége, korábbi veszteségei és annak feldolgozása, előzetes (mentális) betegségei, jelenlegi pszichés státusza, kulturális háttere, vallásossága, szociális kapcsolatrendszere. Mindezekből adódóan a gyászfolyamat mindig egyedi. 
Szövődményes gyász akkor jelenik meg, ha az egyén gyásza jelentősen eltér az adott kulturális környezet szokásaitól, ha olyan testi, pszichés tünetek jelentkeznek, amelyek szaksegítséget igényelnek. Komplikált gyászra hajlamosít:

- a váratlan veszteség,

- a túl erős kötődés az elhunythoz,

- az ellentétes érzések az eltávozottal kapcsolatban,

- gyermek, illetve fiatal halála,

- halmozott, illetve feldolgozatlan korábbi veszteségek,

- a gyásszal egyidejűleg fellépő egyéb stresszhelyzetek,

- hiányos szociális kapcsolatok,

- az erőszakos halál,

- ha a túlélő olyan balesetben veszít el valakit, amelynek saját maga okozója volt,

- a rossz testi vagy lelki egészség,

- és ha a gyászoló már korábban depresszióban szenvedett (Pilling, 2003).

Perinatális halál esetén ezek közül a tényezők közül több is jelen lehet, így a szövődményes gyászfolyamat szinte elkerülhetetlen.

\section{A perinatális gyász jellemzői}

„A gyász annak az átérzése, hogy az elveszitett személy része saját énünknek; ehhez társul annak a kínos érzése, hogy a halált saját részünk elveszitéseként éljük át." (Kovácsné Török, Szeverényi \& Hetey, 1995) A magzat halála az anyában azt az érzetet keltheti, hogy egy testrészét veszítette el. Ezt láthatóan támasztja alá az eddig növekvő, most pedig már lelapult pocak. A gyermek halála szétrombolja a nő saját magába vetett hitét. Úgy érzi, kudarcot vall mint anya, mert nem tudta megvédeni, kihordani magzatát. Kudarcként élheti meg feleségszerepét, mert „nem tudja férjét megajándékozni egy gyermekkel”. A szülők elveszítik a generativitás megélésének egy vágyott, előrevetített módját, a jövőbe vetett hitüket (McAdams, 2018). A nő gyermekkori álma arról, hogy élö, saját babát dédelgethet, meghiúsul, anyává való érése is megakad. Az önvád, a bűntudat főleg az édesanyában lehet nagyon intenzív. Súlyosbítja az a tény, hogy a halál oka gyakran ismeretlen marad a szülők elött, ezért többszörös tehetetlenséget élnek át. A bizonytalanságot növeli az is, hogy a babáról általában semmi konkrét emlékkép nem marad. A szükebb, illetve a tágabb környezet gyakran elfordul a gyászolóktól, a szülőket mintegy kommunikációs zárlat veszi körül (Sz. Makó \& Veszprémi, 2017). Azok az édesanyák, akiknek nem volt módjuk megnézni halott gyermeküket, illetve semmilyen tárgyi emléket nem kaptak velük kapcsolatban, és nem is temethették el a kicsit, még évekkel később is hiányként élték meg ezt, s szignifikánsan magasabb szorongást mutattak, mint azok az édesanyák, akik élhettek ezzel a lehetősséggel. Ha az édesanyának nincs rá lehetősége, hogy optimális körülmények között elbúcsúzhasson a gyermekétől, fennáll annak a veszélye, hogy fantáziájában csecsemőjéről torzult képet hordoz, amely még évekkel később is megjelenik álmaiban, képzeletében, növelve ezzel szorongását, indukálva egy állandó, mély fájdalmat, nehezítve ezzel a gyász egészséges feldolgozását (Gávai \& Molnár, 1997; Kovácsné Török, 1996; Kovácsné Török \& Szeverényi, 1998). A gyász kínzó napjaiban fontos eldöntendő kérdés, hogy mi legyen a baba holttestével. Vajon a szülők szeretnének gondoskodni a temetésről, vagy a kórház szállítja el a holttestet? A gyász feldolgozásának szempontjából 
nagyon fontos kérdéssel állunk szemben. Ha a szülök nincsenek ennek lelki hátterével tisztában, valamint nem kapnak megfelelő felvilágosítást és gyakorlati segítséget a holttest kiadásának lehetőségéről, a temetéshez szükséges dolgok intézéséről, a lesújtottság érzése, a beszükült tudatállapot nem megalapozott döntéshez juttatja el őket.

\section{A perinatális veszteség nehézségei a családi kommunikációban}

A perinatális veszteséget megélt párok, testvérek, többgenerációs családok körében végzett kvalitatív kutatás eredményei arra utalnak, hogy a veszteség hatására több síkon és egyidejüleg lép fel zavar a kommunikációban. A születés körüli veszteség több tabut is érint: a születését, a halálét és a gyermek elvesztéséét (Bornemisza, B. Erdős, s.d.). Az ezekről való kommunikálásra gyakran nem találunk szavakat (B. Erdős, 2018), így a párok, a szülők, a gyerekek és a testvérek, valamint a nagyszülők között kommunikációs zárlat alakul ki, ami megnehezíti a gyász feldolgozását. Az egész család életét megkeserítő játszmák épülhetnek fel a családi titok megtartása, a családtagok egészségének „megőrzése” érdekében. Természetesen ezek a titkok, a jelentős családi erőfeszítéssel elnémított történetek nem az egészséges, fejlődést biztosító egyensúlynak, hanem a mentális problémák kialakulásának kedveznek. A további feldolgozást, a gyászmunkát nehezíti, ha a párok, a család számára elérhető társas támogatás kevés: a házastársi kapcsolat minőségén túl döntő a gyógyító személyzet támogató munkája és a tágabb szociális háló szerepe. Lehetséges, hogy a halál feldolgozására a családon belül nincs lehetőségük, hogy a halál elött is szegényesek voltak megküzdő stratégiáik, vagy a halált követően romlott ezek hatékonysága, illetve általános egészségi állapotuk gyenge (SZNSZK \& OGYEI, 2010).

Az alábbiakban olyan interjúszövegekből idézünk, amelyek felnőttekkel készültek, és a gyermekkorban átélt perinatális gyászról, annak nehézségeiről szólnak - a testvérek szemszögéből. A húsz fő bevonásával zajló kutatás 2019-ben vette kezdetét. ${ }^{1} \mathrm{Az}$ interjúalanyok kiválasztásának két fő szempontja volt: korábbi perinatális veszteség a származási családban, és a kutatás időpontjában betöltött 18. életév. A félig strukturált interjúk az interjúalanyok otthonában készültek, és a veszteség témájára, körülményeire összpontosítottak: a szülöi gyászra, a gyász hatására a túlélő testvér gyermekkorára, további életére, és a megküzdési módokra. Az interjúk a megkérdezettek beleegyezésével rögzítésre és szó szerinti átírásra kerültek. Az interjút követően az interjúalanyoknak módjában állt szabadon reflektálni a beszélgetésre. Az alábbiakban négy személy, egy férfi és három nő történeteinek témánkhoz kapcsolódó részleteit olvashatjuk.

A halálesetek húsz-harminc éve következtek be, egy olyan időszakban, amikor a szokások, a szakmai ismeretekre alapozott protokollok, irányelvek helyett az egészségügyi kommunikáció esetlegessége határozta meg a helyzetet. Az interjúkból kiderül, milyen fontos szerepe lett volna az értő kommunikációnak, a teljes család számára nyújtott támogatásnak. Ma, a járványhelyzetben, a segítő rendszerek túlterheltté vagy nehezen elérhetővé válhatnak, így a perinatális veszteséget elszenvedő családok hasonló, az életüket hosszú távon befolyásoló nehézségekkel szembesülhetnek. Az interjúalanyok számára máig eleven emlék az, amit akkoriban nem értettek, de gyermekként nem is érezték feljogosítva magukat arra, hogy megkérdezzék. Az idézetekben az interjúalanyokat a nevük kezdőbetüjével jelöljük:

\footnotetext{
${ }^{1}$ Etikai engedély száma 2/2019, PTE Szociális Kutatásetikai Bizottság.
} 
A.: „Apukám testvérének, a húgának az autójával mentünk be a kórházba, és beszélgetett apukám a testvérével. És hogy volt egy elvetett mondat, hogy a testvérétől, a M.-tól, hogy nagyon sajnálja, és hogy... különösen azt, hogy még egy elment."

G.: „Amikor elkezdték a nagyobb testvéreim, hogy nem tudom, ... mondjuk most, most velem kivételeznek mindig, mert ez csak azért van, mert meghalt a másik baba. Azért ilyet, nagyon rossz volt ilyeneket hallani. Érteni nem értettem. Azért a nyomását éreztem ennek a dolognak, de nem tudtam mit kezdeni vele."

G.: „Furcsa, hogy aput most nem tudnám megmondani, hogy ő viszonyult-e egyáltalán ehhez valahogy, de ez inkább az, hogy ő nem... magába fojtja az érzéseit, tehát hogy nem jelenik meg ezzel kapcsolatba érzés. Vagy ha beszél is róla, nagyon tárgyilagosan teszi. Tehát olyan... olyan kép... van erröl, hogy 'Ez van. Ilyen az élet. Ez történt. Ne agyaljuk túl.' Hogy aztán mélyebben mi van benne, vagy ő akkor hogy élte meg, azt nem tudom."

Gyakran a tágabb környezet sem tud empatikusan a gyászoló felé fordulni. A kulturális sablonok érzéketlensége, személytelensége, a média üzenetei a gyász személyes élményvilágával érintkeznek, hatnak. A kialakuló értelmezések jól tükrözik a halál tabuként való jelenlétét a kultúránkban, illetve az egyén személyes viszonyát a veszteséghez:

A.: „És álltunk ott az évnyitón, szeptemberben, az osztályfőnök kérdezte, hogy mi van a tesómmal, megszületett-e már. És én akkor le voltam forrázva, és annyit mondtam csak, hogy meghalt. És aztán nagy csönd volt, ő nem kérdezett, én nem válaszoltam, korábban nem hirdettem ki, senkinek nem szóltam semmit, aki hallotta, hallotta, aki nem, nem, de aztán jött az első osztályfőnöki óra, ahol kitért erre a dologra az osztályfönök, és hát azt mondta, ami engem teljesen padlóra vitt, hogy jó, hogy meghalt, mert nem tudtátok volna fölnevelni."

E.: „(...) egyszer apukám elszólta magát. Éppen egy ilyen, ebben a témában [szervkereskedelem] volt egy riport a tv-ben és... és ö hozzászólt. Ott voltunk mindannyian a nappaliban, hogy... valószínüleg velünk is ez történt."

V.: „Szoktunk néha róla így beszélgetni, ilyen kis kedves történetekként, mikor mondjuk a R.-nak elmesélte a Mami, hogy őt most nem hozhatta haza, de majd lesz másik, nem baj. És akkor ezzel párhuzamosan mindig mondják, hogy amikor egyszer a Nagyi megkérdezte a R.-t, hogy szomorú lesz-e majd, ha ö meghal, akkor a R. arra is azt mondta, hogy nem baj, majd lesz másik [azaz másik Nagyi].”

\section{Az egészségügyi személyzet és a kórházi szociális munkás szerepe a kommunikáció segítésében}

A kórházi személyzet szerepe alapvetően fontos a szülők mentális egészsége szempontjából, hiszen ott kapnak azonnali, hatékony segítséget, ahol a tragédia történt. Gávai és Molnár (1997) valamint Kovácsné Török (1996) korai vizsgálatai igazolták, hogy az édesanyák ebben a tragikus helyzetben az érzelmi támaszt elsősorban az egészségügyi személyzettől várták, s akik megkapták, azokban csökkent a szorongás, míg azoknál, akikkel elutasítóan, vagy közömbösen bántak, még évek múlva is fokozott szorongás jelentkezett, és saját egészségi állapotukat is rosszabbnak ítélték meg. A helyzetre vonatkozó irányelvek alkalmazásának alapvető feltétele, hogy az egészségügyi személyzet megfelelő segítséget tudjon adni, átlátva a helyzet pszichoszociális jellegzetességeit. Involvált és empatikus legyen, de védje magát az erős distressztől, a kiégés veszélyeitől. Ezen túlmenő terápiás segítségre, ennek közvetítésére a gyászfolyamat patológiás torzulása esetén van szükség: 
A.: „1992 júniusában, ööö hétfőii napon született, akkori történések ezek, és kedden, mikor mondták, hogy nem láthatjuk, és én nagyon nagyon, nagyon mérges voltam, és nem tudtam mire vélni, hogy miért történhetett... meg olyan, hogy megszületik egy gyerek, azt tudják róla, hogy nincs esélye az életre, beteszik egy inkubátorba, és se az anyukája, se az apukája, se a testvérei nem láthatják, még akkor sem, mikor... amikor... ők kérik, kifejezetten kérik, miért jobb az, hogy egy ilyen gyerek önmagában szenved, miért nem... ha meg kell halnia, akkor most nem mindegy, hogy szerető karok közt hal meg. És én ezt... ez nekem azóta is egy nagyon nagy fájdalmam, hogy... és ezt nem is tudtam a szüleimmel átbeszélni, mert ők mondták, hogy ők... utólag azt, hogy ök nem akarnának a kórházzal szemben fellépni, (...) merthogy ők le akarják ezt zárni magukban."

E.: „Akkor mondták neki a nővérek, hogy nincs itt, a M.-on van a megyei kórházba, átszállították, de meg is halt. (...) és próbált mindenkit kérdezgetni, a szülésznőt, mondják el, mi történt az ő lányával. És senki nem foglalkozott vele, nem válaszoltak neki, egészen addig, amíg el nem kezdett torkaszakadtából ordítani a szülészet közepén, hogy mi történt az ő gyerekével, valaki azonnal mondja meg."

G.: „Sőt, szinte nem is engedték, mert hogy azt mondták, hogy ez mennyire traumatizáló, meg se nézze az anyuka. Emlékszem, hogy ez gyerekkoromban azért így nagyon megérintett, hogy mi az, hogy meg se lehetett nézni."

G.: „Ott helyben mondták nekik, hogy akkor ezt most el kell dönteni. Hogy akkor most ők elviszik, és ők eltemetik, vagy ottmarad, vagy hamvasztják, vagy mi legyen vele. Úgyhogy ez egy hirtelen dolog volt nekik, nyilván az is, hogy akkor utána a két kicsi gyereknek hogyan mondják el, hogy nem jön haza a kis G.”

\section{Összegzés}

A Covid-19-járvány hosszúra nyúlt hónapjai alatt az egészségügyi intézmények látogatási tilalmat rendeltek el. A fenti intézkedés járványügyi szempontból egyértelmüen szükséges, de az egészségügyi személyzet és a szülők, hozzátartozók közötti, adott esetben a felelös döntésekhez szükséges kommunikációt, a gyász korai szakaszában nyújtott támogatást jelentősen megnehezíti. A perinatális veszteséget megélő testvérek narratíváiból láthatjuk, milyen fontos szerepe van a veszteség idején a családnak, rokonoknak, barátoknak, a kórházi szakdolgozóknak. A veszteséggel való megküzdésben az elérhető támogatások integrálásával mind a kórházi szociális munkásoknak, mind pedig a területi védőnőknek fontos szerepe van. A járvánnyal kapcsolatos szigorú intézkedések ezt a fajta komplex segítségnyújtást ma több ponton beszükítik, vagy egyenesen lehetetlenné teszik.

Ugyanakkor a hazabocsátás után az anya csak érintőlegesen és véletlenszerüen áll orvosi ellenőrzés alatt. Ekkor a szülői gyász elősegítése, támogatása leginkább a védőnő szakmai kompetenciájának körébe tartozhat. Ö az, aki a prevenció területén a leghatékonyabb munkát tudja végezni, és szükség esetén a család, vagy az egyes családtagok számára terápiás segítséget közvetíthet. Fontos odafigyelnünk rá, hogy a megmaradt lehetőségek közül maradéktalanul nyújtsuk azt a segítséget, amit az óvintézkedések megengednek.

\section{Irodalom}

Bornemisza Á. \& B. Erdős M (s.d.). Perinatális gyász a túlélő testvérek életében: A testvérvesztés jelenségvilágának párhuzamai a Hét holló c. mese és hét interjú tükrében. Kharón, lektorálás alatt.

B. Erdős M. (2018). „Úgy érzem, mintha kiesnék ebből a világból.” A lélektani krízis átmeneti tapasztalatának narratív sajátosságai. ["I feel as if I fell out of this world": Narrative 
characteristics of the transitional experiences of psychological crisis.] Magyar Pszichológiai Szemle, 73(1), 59-81.

Funk, A. M., Jenkins, S., Astroth, K. S., Braswell, G. \& Kerber, C. (2018). A narrative analysis of sibling grief. Journal of Loss and Trauma, 23(1), 1-14.

Gávai M. \& Molnár G. (1997). Sikertelen terhesség utáni gondozás. Háziorvos Továbbképzö Szemle, 2(4), 306-307.

Kovácsné Török Zs. (1996). Hol van a Kisherceg: a csillagokban, vagy a szívünkben? Pszichoterápia, 5(6), 393-397.

Kovácsné Török Zs., Szeverényi P. \& Hetey A. (1995). A gyász folyamata: a normál és a patológiás gyászmechanizmus. Magyar Pszichológiai Szemle, 51(3-4), 243-249.

Kovácsné Török Zs. \& Szeverényi, P. (1998). A vetélés és a szülés körüli gyermekelvesztés a pszichológus szemével. Kharón, 2(1): 33-40.

McAdams, D. P. (2018). "I am what survives me": Generativity and the self. In J. A. Frey \& C. Vogler (Eds.), Self-transcendence and virtue: Perspectives form psychology, philosophy and theology (pp. 251-273). Routledge.

Mucsi G. (2015). A halálkép jellegzetességei hospice ellátásban dolgozó szociális munkások és az önkéntes tevékenységet végzök körében (Doktori disszertáció). Pécsi Tudományegyetem.

Pilling J. (szerk.) (2003). Gyász. Medicina Kiadó.

Sz. Makó H. \& Veszprémi B. (2017). A párkapcsolattól a gyermekágyig. Octoport Nonprofit Kft.

SZNSZK (Szülészeti és Nőgyógyászati Szakmai Kollégium) \& OGYEI (Országos Gyermekegészségügyi Intézet) (2010). A Nemzeti Erőforrás Minisztérium szakmai irányelve a pszichológiai feladatokról szüléshez társuló veszteségek során. Hivatalos Értesítö, 13(104), $15246-15258$.

Zsák É. (2020). Etikai kérdések a perinatális palliatív ellátásban. Kharón Thanatológiai Szemle, 24(2), $15-29$. 